\title{
RELIGIOUS SYMBOLISM AND DEMOCRACY ENCOUNTERED: \\ A Case of Prostitution Bylaw of Bantul ${ }^{1}$
}

\section{Muhammad Latif Fauzi}

State Institute for Islamic Studies of Surakarta, Indonesia

\begin{abstract}
This paper addresses the bylaw on prostitution issued by the Bantul authority in May 2007. It specifically examines the relation between the involvement of religious symbolism, the call for public participation and political interests in the legislation process. The paper argues that, on the one hand, the law relates prostitution to issues of immorality, social illness, and the degradation of women due to economic discrimination or sexual exploitation. The subject of prostitution has been extended, covering not only sex workers and pimps, but everyone committing indecent acts, such as showing a 'sexy' performance. On the other hand, this regulation is considered to be ambiguous in determining the standard of public morality and, therefore, puts women in a marginalised position. That the implementation of this law contributes to institutionalising the criminalisation against women is another fact which is believed to diminish the meaning of democracy. The government is blamed as taking too much care with procedural democracy but giving less attention to education and employment opportunities.
\end{abstract}

[Artikel merupakan hasil studiperaturan daerah tentang larangan pelacuran yang dikeluarkan oleb Pemerintah Kabupaten Bantulpada Mei 2007. Studi ini menguji keterkaitan antara simbol-simbol keagamaan, partisipasipublik, dan kepentingan politik yang muncul dan menyertai proses legislasi. Penulis

${ }^{1}$ This paper is part of my research report supported by the Islamic Research Programme (IRP), the Dutch Ministry of Foreign Affairs and Leiden University. 
berpendapat bahwa pada satu sisi, dalam peraturan tersebut, pelacuran dikaitkan dengan perusakan terbadap nilai agama dan sosial serta penurunan martabat perempuan, terlepas akibat diskriminasi ekonomi atan eksploitasi seksual. Subjek, pelacuran ternyata juga diperluas, tidak banya pekerja seks dan mucikari, tetapi setiap orang yang melakukan perbuatan cabul, seperti berpenampilan seksi. Pada sisi yang lain, ukuran moralitas publik. dalam peraturan ini dianggap kurang jelas dan menempatkan perempuan pada posisi yang terpinggirkan. Babwa penerapan peraturan berimplikasi pada kriminalisasi terhadap perempuan merupakan bukti lain yang dinilai bertentangan dengan substansi demokrasi. Pemerintah dinilai terlalu perbatian pada demokrasi prosedural, tetapi mengabaikan masalah pendidikan dan kesempatan kerja.]

Keywords: prostitution, religious symbolism, procedural democracy

\section{A. Introduction}

Local autonomy and decentralisation is one remarkable development in Indonesia after the collapse of the New Order regime in 1998. The increasing number of regional regulations has served as significant evidence of effective decentralisation. Such regulations do not limit their reference to national laws, but also draw from religious doctrines. In this respect, the so-called shari' $a$ regulations, including regulations on prostitution, are considered to curtail the value of democracy itself. A number of laws ${ }^{2}$ have served as the legal basis for regional authorities to promulgate local regulations. Article 10 in the Law 10/2004 declares that "the content of district regulation is all materials that support the application of district autonomy, assistance tasks, and district specific aspirations as well as further explanation of the higher Laws."

Relating to the aforementioned legal issues, several Muslim dominated districts and cities, such as Kota Padang, Bukittinggi, Cianjur, Tangerang, Jombang, Bulukumba, and Tasikmalaya, have inaugurated their Islamic political aspirations through the ratification of shari' $a$ regional

2 They include Law 22/1999 on Otonomi Daerah (Regional Autonomy) which was afterwards renewed with Law 32/2004 on Pemerintah Daerah (District Government) and Law 10/2004 on Pembentukan Peraturan Perundang-undangan (Formulation of Laws). 
regulations. ${ }^{3}$ The implementation of shari' $a$ in the era of local autonomy is not without controversies and has provoked reactions. Some are worried about the fact that government leaders use shari' a bylaws to garner votes from constituents through the politicisation of religious values. Instead of preserving a religious spirit, such bylaws lose their religious authority by becoming linked to government's interest. ${ }^{4}$

These regulations have been criticised as having trampled on the rights of citizens, particularly women. The Komisi Nasional Anti Kekerasan Perempuan (the Indonesian National Commission on Violence against Women, referred to as Komnas Perempuan), reports that from 1999 to 2009 there were 154 ratified regional regulations which support the institutionalisation of discrimination, both in their objective and/or impact. Among them, 19 regulations were issued at the provincial level, 134 at the district/municipality level, and 1 at the village level. These ordinances are regulated in 69 districts/municipalities in 21 provinces and about 80 regulations were promulgated from 2003 to 2005 . No more than 39 regulations are enacted to recover the rights of victims. ${ }^{5}$

$63(40 \%)$ of shari' $a$ bylaws are claimed to be supportive of discrimination and violence against women. ${ }^{6}$ Discriminative policy is represented in a number of regulations on public order and religious symbolism at large. ${ }^{7}$ Discriminative regulations include several issues such as the restriction of freedom of expression in 21 regulations on dressing

${ }^{3}$ Robin Bush, "Regional Sharia Regulations in Indonesia: Anomaly or Symptom?" in Greg Fealy and Sally White (ed.), Expressing Islam: Religious Life and Politics in Indonesia (Singapore: Institute of Southeast Asian Studies, 2008), pp. 174-191.

${ }^{4}$ Sukron Kamil (ed.), Syariah Islam dan HAM: Dampak Perda Syariah terhadap Kebebasan Sipil, Hak-bak Perempuan, dan Non-Muslim (Jakarta: CRSC UIN Jakarta and Konrad Adenauer Stiftung, 2007).

${ }^{5}$ Komnas Perempuan, Atas Nama Otonomi Daerab: Pelembagaan Diskriminasi dalam Tatanan Negara-Bangsa Indonesia (Jakarta: Komnas Perempuan, 2010), p. 19.

${ }^{6}$ Ibid.

${ }^{7}$ According to Salim, perda shari'a can be mapped into three categories, i.e. 1) public order and social problems outlawing prostitution, gambling, and alcohol consumption; 2) religious skills and obligations on reading the Qur'an, paying the rakat (alms); and 3) religious symbolism on the wearing of Muslim clothing and jilbab. The last two can be said to be directly linked to Islamic teachings while the first is related to 'morality issues' as most religions and the majority of Indonesian society. Arskal Salim, 'Muslim Politics in Indonesia's Democratisation,' in R. McLeod and A. MacIntyre (eds), Indonesia: Democracy and the Promise of Good Governance (Singapore: ISEAS, 2007), p. 126. 
code, the decrement of the rights to protection and legal certainty for criminalising women in 37 laws banning prostitution, the abolition of the rights to protection and legal certainty in 1 regulation on the prohibition of khalwat (close proximity), and the neglect of the rights to protection in 4 bylaws on migrant workers. ${ }^{8}$ Regulation criminalising women, including those on prostitution, makes the biggest number of regulations.

In 2007, the Bantul district administration issued a bylaw banning people, either in public places or locations visible from public places, from enticing others into acts of prostitution. The regulation was officially declared by the House of Representative (Dewan Perwakilan Rakyat Daerah, DPRD) of Bantul on 12 April 2007, then validated on 1 May 2007 and registered as Peraturan Daerah (Perda) No. 5/2007. It has been claimed to be an instrument assisting Bantul in becoming a district which affords democracy, religiosity and welfare for its people. It is also positioned as an effort (ikbtiar) to clean vices (maksiat) and confirms it as the government's responsibility to attend to social orders, relating to women particularly.

Right-wing Muslim organisations call for the enforcement of this regulation. Prostitution is profoundly positioned to be degrading to women who are forced into it, either due to economic discrimination or sexual exploitation. Opposition to this bylaw has been voiced by a number of activists. According to them, the Perda was drafted in a nontransparent way, did not include public participation and was merely aimed at wooing Muslim voters. This regulation has legal weakness and violates the principles of human rights and justice. The other position, mainly argued by feminists, ${ }^{9}$ views that prostitution is an acceptable profession that many women would choose to enter.

This paper questions to what extent religious symbolism and political contestation have interfered in the making of such a regulation. In

\footnotetext{
${ }^{8}$ Komnas Perempuan, Berita Komnas Perempuan, Edition 5, September 2010.

${ }^{9}$ In the case of the Bantul regulation, this feminist view is represented by a number of non-governmental organizations working on women issues, such as PKBI DIY (Perkumpulan Keluarga Berencana Indonesia Daerah Istimewa Yogyakarta or the Indonesian Planned Parenthood of Yogyakarta) and Perempuan Mahardhika. They work together to criticise the regulation through an association called Aliansi Tolak Perda Larangan Pelacuran di Bantul (ATPLP, the Alliance for the Opposition to the Bantul Regulation on the Prohibition of Prostitution).
} 
so doing, this paper will being by giving a brief overview on the historical account of the emergence of prostitution in Bantul, Parangkusumo in particular. An exploration on the process of the Perda formulation follows afterwards. The paper ends up with an analysis on engaged political actors and contested interests, emerging religious symbols, and the ways democracy and public participation are manifested.

\section{B. From the Cepuri Pilgrim to Sexual Favours: An Historical Account}

Organised forms and the related problems of the sex industry in Indonesia have emerged and expanded since the Dutch colonial era. In 1852, the government recognised prostitution in an act regulating those working in the commercial sex industry 'to avoid harmful consequences resulting from prostitution.' Sex workers were suggested to operate in brothels to help police control them. Later, this provision was problematic as the act was understood to have legitimised brothels as commercial institutions. In 1858, another law was eventually issued to clarify the 1852 act. Brothels were positioned as places 'to limit the harmful effects' of prostitution by regularly having medical consultation. ${ }^{10}$

The later growth of the plantation and sugar industries in East and Central Java, the opening of private capital, and the significant migrations of male workers to Java created a huge demand for the service of prostitution. The building of roads and railways also greatly expanded prostitution. In line with this constructed infrastructure, cities passed by the railway were aggressed by the increase in the number of rail passengers. Their arrival demanded rooms and lodging, including for sexual services. In Yogyakarta, the prostitution centre is located in the area of Pasar Kembang, a few meters from the Tugu rail station. ${ }^{11}$ Not limited in this complex, in the 1990s pimps brought sex workers to other places, mainly to the south coastal areas such as Parangbolong and Parangkusumo.

Parangkusumo, located $28 \mathrm{~km}$ south of Yogyakarta, is familiar to Yogyakartans. In addition to the beauty of its beach, it is well known for

${ }^{10}$ Gavin W. Jones, Endang Sulistyaningsih, and Terence H. Hull, "Prostitution in Indonesia," Working Paperin demography at the Australian National University, 1995.

${ }^{11}$ Ibid. 
a pair of rocks surrounded by walls called Cepuri. Villagers believe the rocks to be sacred and mystical where Kanjeng Panembahan Senopati, the first King of the Mataram Kingdom, was said to have meditated at the time. Many people said that it was here that the King met with Kanjeng Ratu Kidul, the Goddes of the South Sea of Java, for the first time. Cepuri is thus considered as an important place for spiritual and cultural events. Visitors cannot freely go in and out of this complex and must be accompanied by a spiritual guardian (juru kunci). Sandals have to be taken off before entering. They are obliged to be silent inside the site.

Rituals in Cepuri can be performed on all days and at any time. Nevertheless, Tuesday Kliwon ${ }^{12}$ and Friday Kliwon are believed to be particularly special moments to undergo pilgrimage. In addition to pilgrimage, the offering to Kanjeng Ratu Kidul or labuban ${ }^{13}$ is considered a very important part in the ritual. ${ }^{14}$ The choice of those two nights relates to a Javanese tradition which regards them holy and sacred. ${ }^{15}$

Modernisation and economic development have, however, altered the adherence of these activities. Since the 1980s, economic activities in Parangkusumo have come to dominate these ritualistic practices. Traders offer goods, such as clothes, traditional medicine, and massage services. People from Yogyakarta and its neighbouring areas, come there either to shop or have a night of pleasure. The rise of economic activities, mainly on the regular ritual days, as well as the increasing number of houses in Parangkusumo, amplified the variety of products and services promoted. The commercialisation of sex has been one eventual consequence. According to RP Suraksotarwono, the juru kunci of Parangkusumo, the first sex workers were those who worked in Pasar Kembang in Yogyakarta. Some villagers enjoyed this considerable business development as it has

${ }^{12}$ Kliwon is one of the Javanese days, called pasaran. Other days include Legi, Pabing, Pon, and Wage.

${ }^{13}$ Labuhan is a traditional ceremony of throwing offerings and flowers into the South Sea (Indian Ocean).

${ }^{14}$ Maharsi, "Varian Keagamaan Masyarakat Pesisir Pantai Selatan (Studi Kasus Desa Parangtritis, Kretek, Bantul, DIY)," Jurnal Penelitian Agama, 13, 3, SeptemberDecember 2004.

15 This belief is close to a tradition that a Javanese who performs 40-days-fasting usually ends on Friday Kliwon or Tuesday Kliwon. Nevertheless, this tradition tends to change nowadays. Instead of 40 days, locals start to replace this tradition with 3 daysfasting on Wednesday Wage, Thursday Pon, and Friday Kliwon. 
invited a huge number of costumers from diverse cities. ${ }^{16}$

This success story made the extent of prostitution increase dramatically and invited hundreds of sex workers from varied cities. Sex workers, who used to be called Wanita Tuna Susila/WTS (women lacking moral) and now commonly referred to as Pekerja Seks Komersial/PSK (commercial sexual worker) come regularly to seek costumers. However, only a small number of them are from Yogyakarta as most of them come from districts in Central Java, such as Demak, Pati, Magelang, Solo, Purwodadi and Sragen. Most are "free lancers" and not attached to pimps. All the pimps rent rooms to sex workers and earn IDR 10.000 for each use.

Initially, sex workers only came to Parangkusumo on Tuesday and Friday Kliwon nights. Later on, considering the potential income, they preferred to stay permanently rather than regularly commute. Other resident's also benefit from this situation in many forms. The most obvious places where such business is conducted are brothel complexes, hotels, massage parlours, and karaoke rooms. In addition, many villagers have opened stores selling foods, cigarettes and daily needs. Thus, the relation between the sex industry and other economic activities in general cannot be ignored. ${ }^{17}$ The more-dominant colour of prostitution somehow had displaced the meaning of ritual. In daily speak, sex is also called ritual. Many people even have named "Hari Ibu (Mother Day)" a ritual day as many sex workers are between 35 to 40 years (and so the age of a mother).

The tariff for purchasing their service varies depending on how capable a costumer is at bidding. In general, young sex workers would set the tariff from IDR 70.000 to IDR 150.000, while older sex workers tend not to set the exact fare. Costumers usually pay from IDR 25.000 to IDR 35.000. The more beautiful a prostitute looks like, the higher the cost. From 2000 to 2006, it was likely that a young prostitute could have twenty costumers a night. ${ }^{18}$

Anik, an ex-pimp, clarified that her store might circulate five

${ }^{16}$ Interview with RP Suraksotarwono, the spiritual guardian as well as the elder generation in Parangkusumo, August 2011.

${ }^{17}$ Interview with Daru Waskita, journalist, in Bantul, July 2011.

${ }^{18}$ Interview with Yani, sex worker, in Parangkusumo, July 2011. 
packages, each containing 144 items, of condoms a month. ${ }^{19}$ On the ritual nights, through renting rooms, the pimps would earn more than IDR 1.000.000 a night. In addition, owners of karaoke halls also made quite reasonable incomes. Someone who rents a karaoke room must pay IDR 25.000-50.000 for an hour. The owner could facilitate to call a PK (Pemandu Karaoke, the karaoke guide) to join, when demanded. The owner does not determine the tariff of using the PK. Usually a costumer has to pay IDR 50.000-75.000 and give the money directly to her. The PK offers the costumer to have karaoke "plus." ${ }^{20}$ For having this service, the customer must pay extra money from IDR 100.000 to IDR 200.000. Despite having no charge from the PK, the owner could still take benefits from selling other products, such as foods, drinks, beers, and rooms for doing "plus" service. ${ }^{21}$ Besides the linkage between sex workers, pimps and karaoke owners, some other types of occupation also indirectly benefit this connection. On the ritual days, bus drivers have more passengers, including pilgrims, sex workers, visitors, and traders and hence reap relatively bigger incomes compared to regular days.

During Ramadhan, Cepuri remains open. The situation in Parangkusumo looks quieter however as the religious atmosphere is clearly visible. The Darus Salam mosque, inside the complex of Cepuri, held a daily iftar (breaking the fasting). A religious gathering (pengajian) targeting a larger audience is carried out weekly. All villagers, including the owners of brothels, are scheduled to donate food for takjil (snack and drink funtion to break the fasting). Mothers, teenagers, and children gather to wait for the coming of the Maghrib prayer. During that time, guided by the imam, they recite Islamic chanting (d₹ikr) as commonly offered to pray for the death. Rituals within the mosque represent the traditional teaching of Islam which is institutionally affiliated with the

${ }^{19}$ Interview with Anik who claimed herself as the caretaker of sex workers. She used to be a prostitute, then a pimp, but now limits her business to karaoke house, July 2011.

20 "Plus" is an Indonesian slang word referring to sexual services. In other cases, if it reads "pijat plus" or "massage plus," someone will understand that it is a massage with sexual favours.

${ }^{21}$ Interview with Budi, the owner of Hesty Karaoke in Parangkusumo, July 2011. 
biggest Muslim organisation, Nahdlatul Ulama. ${ }^{22}$ Prostitution is not strongly evident during Ramadhan evenings.

\section{C. "Religious" Bantul and the Making of Prostitution Bylaw}

The regency of Bantul is located in the southern part of Yogyakarta province, bordering Yogyakarta and Sleman regencies in the north, the Indian Ocean to the south, Gunung Kidul regency in the east, and Kulonprogo regency in the west. Located $10 \mathrm{~km}$ south of Yogyakarta, Bantul has a population of 831,000 people whose occupations include rice farming, craftsmen, factory labour, civil servants and merchants. Subdistricts of Bantul are divided into 3 major areas: west, central and east, consisting of 17 sub-districts and 75 villages. The main agriculture products are rice, sugarcane, and staple crops. The annual income in 2009 was about IDR 88.600.000.000. Based on the 2008 report, the government gained IDR 1.499.115.400 in 2007 from tourism in Parangtritis and Parangkusumo. ${ }^{23}$

Bantul has maintained a vision for its development, i.e. Bantul as a region with Projotamansari, welfare, democratic, and religious people. Projotamansari is an acronym that stands for produktif (productive), ijo royo-royo (green), tertib (orderly), aman (safe), sehat (health), and asri (harmonious). The last mentioned point, religious, specifically characterises Bantul, compared to other regencies. Most of Bantul's people live in lowland and villages who are committed to performing traditional religious practices. The government expects its people to be religious by enhancing their everyday life with religiosity and morality. ${ }^{24}$

Bantul as a religious regency has, in some way, been a common theme among elites and grassroots groups. The area was made a self proclaimed social and political capital by Idham Samawi who ruled

${ }^{22}$ Interview with Ahmad, the imam of the Darus Salam mosque on 11 August 2011. He has been an imam for 17 years. He tended to call sex workers "mbak-mbak nakal" (naughty women). He admitted that his dakwah activity in the area of Parangkusumo was not hampered by the influence of prostitution. However, his opinion seems to represent the traditionalists' perspective on prostitution which differentiates bad girls and good girls. The bad girls meet men's need for sexual orientations while the good girls meet men's need for nurturers.

${ }^{23}$ Bantul Statistics Bureau, Bantul in Figures (Bantul: BPS, 2008), p. 320.

${ }^{24}$ See the profile of the Bantul district on its website: www.bantulkab.go.id 
Bantul for two terms, 1999 to 2004 and 2004 to 2009. Idham Samawi was born in an elite religious family. Haji Samawi, his father, was one of the founders of Kedaulatan Rakyat, the first newspaper in Yogyakarta, which was established on 27 September 1945. The family nobility strengthened the position of Idham Samawi. In addition, his wife, Sri Suryawidati who replaced him as regent head, has in some way strengthened the dynastic power of Samawi family in Yogyakarta. Though her capability was underestimated, she won the 2009 regent head election by relying upon the popularity of her husband whom was considered to be successful in governing Bantul. ${ }^{25}$

The rise of Idham Samawi as the regent of Bantul occurred during a time when the Indonesian government was challenged by the implementation of a new approach of national development through decentralisation and regional autonomy. The concept of decentralisation was provisioned in Law 22/1999 on Local Government and Law 25/1999 on Financial Balance between the Central Government and Regional Government. Both laws, in principle, formally state that regional authorities (provinces, districts, and municipalities) have full autonomy to govern and admin the interest of local people within the boundary of the state of the Republic of Indonesia. The first-mentioned law was ratified by Law 32/2004 on Regional Government.

In the spirit of decentralisation, during the Idham Samawi period, the Bantul administration issued some local regulations concerning social orders, one of which was a response to the prostitution in south coastal areas, a matter of serious concern for the Bantul authority. Though the discussion started in 2002, the official legislation occurred in 2007. The legal basis for such legislation was the Introductory Note (Nota Pengantar) on the Draft of Bantul Regulation (Rancangan Peraturan Daerah, Raperda) which was written and submitted by the Regent and read in the Plenary Meeting (Sidang Paripurna) of the Bantul legislative on 15 March 2007. Attached with this note, the Draft of the Regulation on Prostitution was delivered to the members or parliament. ${ }^{26}$

25 "Rezim Keluarga di Pilkada," Kompas, 19 April 2010. The result of the Regent election on 23 May 2009 shows Sri Suryawidati-Sumarno gained 67,77 percent, Sukardiyono-Darmawan Manaf 28,26 percent, and Kardono-Ibnu Kadarmanto 3,97 percent.

${ }^{26}$ Nota Pengantar Bupati Bantul. 
The Raperda, drafted by the sub-division on law, claimed to rely upon social aspirations. Three meetings held in January 2007 involving state officials, social and religious elites, and grassroots activists all drew to a single conclusion that prostitution had been a serious problem in terms of religious and social norms. During two days right after the meeting, the parliamentary factions ${ }^{27}$ prepared a Public Hearing (Pemandangan Umum) concerning the note of the Regent. It was on 20 March 2007 that the plenary meeting heard, for the second time, the general overviews of the factions. The majority of them asserted the necessity of the Perda and recommended the establishment of a Special Committee (Panitia Khusus, Pansus) to discuss and examine the draft. ${ }^{28}$ At the same time, the regent also formed an executive team whose main task was to guarantee that the draft had to come to legislation.

The bill was eventually legalised on 27 April 2007, registered as Perda No. 5/2007 and validated on 1 May 2007. Health, public safety, law order and social harmony, violation of God's law, immorality, and morally-correct behaviour (akblak, karimah) are selected to emphasise its legal reasoning. As described in the consideration, this law was legalised in order to arrest not only sex workers, but more importantly, pimps and brothel owners. In the section of punishment it is stated that anyone breaking this provision receives 3 months imprisonment or is fined IDR 10.000.000 at maximum. Many people are doubtful however that this will be fully implemented as, in many cases, pimps are immune from the law force since they usually perfrom as strongmen and have social power in society. It is commonly known that they have a close relation with government leaders, including the law apparatus, which could protect their position from the law power. The law affects those at low level, predominantly sex workers. ${ }^{29}$

${ }^{27}$ There were 6 parliament factions representing the most leading parties in the 2004 Bantul general election, i.e. the factions of Partai Demokrasi IndonesiaPerjuangan, Partai Amanat Nasional, Partai Kebangkitan Bangsa, Partai Keadilan Sejahtera, Partai Golkar, and Kesatuan Baru (a coalition of Partai Demokrat, Partai Persatuan Pembangunan, and Partai Karya Peduli Bangsa).

${ }^{28}$ This data is abstracted from the Official Proceeding of the 15th Plenary Meeting of the Bantul Legislative in 2007.

${ }^{29}$ This can be proved by the cases of prostitution in the Bantul court where defendants are mostly sex workers, not the pimps nor the brothel owners. 
The Pansus is a compulsory step in the legislation process. Unlike the Pansus, parliament faction is not considered to be an official structure within the Council. ${ }^{30}$ Political parties can only bargain their political interests through this circle. The final report represents the existing voices of all the factions. It also plays a decisive role in determining the face of a bill. The head of the Pansus, Edy Susila, represented an Islamic party, PPP (Partai Persatuan Pembangunan, the Unity Development Party), while the secretary, Jupriyanto, was also from another Islamic party, PKS (Partai Keadilan Sejahtera, the Prosperous Justice Party). ${ }^{31}$

This bylaw banning prostitution has led to disputes. Negative reactions and rejections were voiced by communities whose financial sources were affected by the imprudent implementation of the Perda. Community and women groups have strongly criticised the regulation, saying the ordinance is vague and dangerously ambiguous, leaving all women vulnerable to accusations of soliciting prostitution. In the Plenary Meeting of the DPRD Bantul on the Validation of Anggaran Pendapatan dan Belanja Daerah/APBD (the Budget of Income and Expense) 2008, all political factions reemphasised their support of the Perda enforcement on behalf of preserving good religious conduct.

\section{Religious Symbolism and the Loosening Political Platforms}

Prostitution, in the shari' $a$ based local regulations, has become a tremendously topical issue in recent years. Public attention has focused on the situation of female sex workers, the influence on the young generation, the rise of economic activities surrounding the centre, and the adequacy of regulation. Much of the debate over prostitution has been simply polarised between the so-called liberals and conservatives. The first demands prostitution be decriminalised, normalised and humanised while the second argues that prostitution should be abolished. Social political interests play significant major roles in determining government's position between the two poles.

${ }^{30}$ This is according to the law no. 29/2009 on the structure and position of the People's Consultative Assembly (Majelis Permusyawaratan Rakyat, MPR) and the People's Representative Council (Dewan Perwakilan Rakyat, DPRD).

${ }^{31}$ The DPRD Bantul Decree no. 08/KEP/DPRD/2007 on the Establishment of the Special Committee. 
Ronald Weitzer, referring to Kantola and Squires, ${ }^{32}$ categorised discourses responding to political debates on prostitution into four types: public nuisance, traditional morality, oppression-of-women, and sex work. Public nuisance is the most outstanding opposition to prostitution. This discourse is nevertheless silent on the marginalisation against street-class sex workers. Objections to sinful, shameful, and evil prostitution are represented by the traditional-morality model. These characterisations have been used for a hundred years and repeatedly spoken whenever the topic is discussed. In the spirit of modernisation and gender-equality mainstreaming, the oppression-of-women relies not only on sin and vice, but the subordination of women and children. ${ }^{33}$

The oppression model stands on the notion that prostitution is male domination of women. The model regards sex workers as victim and relates prostitution to sex trafficking problems. Those sexually exploited are often economically marginalized women and children with histories of prior physical and sexual abuse. The absence of economic alternatives has made them vulnerable to sex trafficking. The Coalition against Trafficking in Women (CATW) in the section "Who We Are" of its website proclaims that "We must take a principled position against the legalization of prostitution and discourage the demand for commercial sex without penalizing the victims. The wrong people continue to be arrested; the prostituted should be decriminalized." 34 This model's favoured term, 'sexual slavery', is obviously opposed by the sex worker paradigm. Legalisation will institutionalise protection through workers' rights and the decriminalisation of sex workers.

I argue the Bantul authority was inclined to implement the second model, traditional-morality one. Prostitution is placed in the religious and moral paradigm instead of social-economic one. As stated in the Consideration, prostitution is meant as an activity that disparages human dignity and violates religious tenets, the ideology of Pancasila and morality. The Bantul authorities believe that prostitution will harm

${ }^{32}$ Johanna Kantola and Judith Squires, "Discourses Surrounding Prostitution Policies in the UK," European Journal of Women's Studies, 11, 1, 2004.

${ }^{33}$ Ronald Weitzer, "Legalizing Prostitution: Morality Politics in Western Australia," The British Journal of Criminology, 49: 1 (2009) pp. 88-105.

${ }^{34}$ http://www.catwinternational.org/WhoWeAre (accessed on 17 November 2011). 
health, public safety and law order while disturbing social harmony; thus, it must be prohibited. ${ }^{35}$

With regard to the problematic position of prostitution, the legislation process, which took twenty days, is remarkable. This fact somehow demonstrates the low complexities, both sociological and political, that the Bantul authority faced to make this law possible. Muslim organisations, such as NU, Muhammadiyah, and MUI (Majelis Ulama Indonesia, the Indonesian Ulama Council) were invited to write an official letter declaring their favour. More significantly, every single faction, either Islamic or nationalist, walked on the same ground.

The fact that all parties shared a religious outlook in perceiving prostitution was indeed undeniable. They spoke in the same language, i.e. preserving good behaviour and saving a generation, and a few of them placed prostitution in a wider social economic context, such as poverty and job opportunities. A slightly different reasoning for supporting the bill has been used by PKB (Partai Kebangkitan Bangsa, the National Awakening Party) faction. It is argued that prostitution has to do with the market mechanism law; supply and demand. It is about how to slash the mutual ties between the seller (i.e. prostitute) and the costumer. Enforcing the law only for the first mentioned does not truly shoot the trouble. ${ }^{36}$

In this case, the segregation of parties between either religious or secularly inclined is no longer relevant. This can be explained by understanding the political situation when the bill came to legislation. The decline of PDI-P (Partai Demokrasi Indonesia-Perjuangan, the Indonesian Democratic Party-Struggle) and the rise of two political parties, PKS and PD (Partai Demokrat, the Democrat Party) in Bantul are deemed to influence the configuration of political atmosphere. On the one hand, out of 45 seats in the Bantul legislative, the PD only enjoyed 1 seat (2.2 percent) in 2004, and had a significant increase, 5 seats, in 2009. PKS had five seats or 11 percent both in 2004 and 2009. On the other hand, PDI-P, reaped 16 seats ( 35.5 percent) in 2004 but dramatically lost 5 seats $(24.4 \%)$ in $2009 .^{37}$

The above fact leads me to argue that the transformation of the

${ }^{35}$ Perda Kabupaten Bantul No. 5/2007 on the Ban on Prostitution.

${ }^{36}$ The Final Faction Overview of the Partai Kebangkitan Bangsa on Six Bills, read on the Plenary Meeting on 13 April 2007.

${ }^{37}$ Based on data of KPU Pusat and KPU Bantul 
so-called politik aliran (political flows) after the fall of Soeharto remains to continue. ${ }^{38}$ This can be seen from the fact that the current political situation in some local areas in Indonesia presents a picture of the people's loose attachment to political parties, particularly in terms of lessening membership figures and increasing numbers of swing voters. ${ }^{39}$ This phenomenon rebuts the premise that politics has become polarised between Islamic and non-Islamic parties. Moreover, the contrast between urban-based parties and rural-based parties also has blurred. Both religious and non-religious streams went the same direction. They tend to disobey their political ideologies, whereas pragmatic interests appeared dominantly to drive their agendas.

The vast majority of Muslims in Bantul, 791,392 out of 831,986, (or 95 percent), mostly residing in rural areas, is a captive political market. It is not an exaggeration to state that both nationalist or Islamic parties have to compete over their influence in that domain. The PDI-P, which usually avoids utilising religious issues such as the introduction to $\operatorname{shari~}^{-} a$ based bylaws such as pornography and wearing hijab for women, at the regional level is absent. This indication leads me to conclude that speaking for Islam as well as on behalf of Muslim desires is in fact used by parties as a strategic way to win over Muslim voters. It is, hence, relevant to consider Ufen's note on the dynamics of politik aliran in the reformasi era. He said "parties are not 'organic' aggregations of social interests, but are characterised by all kinds of deficiencies. Most of them are ridden with internal conflicts, their financing is often shady, their platforms are vague and party elites tend to monopolise decision making." ${ }^{40}$

Religious symbolism has served as the main reason for the rejection of prostitution. As stated in the Faction Final Hearing (Pandangan Akhir Fraksi), Islamic parties explicitly cited certain verses from the Qur'an. The Fraksi Kesatuan Baru (the New Unity Faction) including the Partai Persatuan Pembangunan related prostitution with God's prohibition on

${ }^{38}$ R. William Liddle, "New Patterns of Islamic Politics in Democratic Indonesia," Asia Program Special Report (Woodrow Wilson Center International Center for Scholars), no. 110 , April 2003, p. 2.

${ }^{39}$ Andreas Ufen, "The Evolution of Cleavages in the Indonesian Party System," Working Paper at the German Institute of Global and Area Studies, April 2008.

${ }^{40}$ Andreas Ufen, "From Aliran to Dealignment: Political Parties in post-Suharto Indonesia," South East Asia Research, 16, 1, p. 6. 
jollification and adultery. The first referred to the Qur'an (sura al-'Ankabut verse 64) cautioning human beings against jollification and pleasures in this world and the endless happiness in the hereafter. The second mentioned was sura al-Isra' verse 32, which explicitly bans human from committing adultery. ${ }^{41}$

Regardless of being in favour of the motion, the faction of the PKS harshly criticised the Perda as it did not define "morality" within religious norms. This faction also regretted the incompleteness of this bylaw as it limited the scope of prostitution and did not include cheating (selingkuh) as an act of prostitution. Machmudi noted that for the PKS promoting shari' $a$ to the state level remains important. PKS prefers to pursue the implementation of shari' $a$ in a smooth way, not a top-down approach, through educating Muslims to understand the essence of shari' $a$. Through this, they practice such teachings in their daily lives and later call for its implementation in governmental policies. ${ }^{42}$

\section{E. The Calls for (Procedural) Democracy and Public Participation}

Prostitution is commonly linked with poverty, poor education, low skill, and intensive labour. However, simultaneously, despite being labelled immoral, they generally get well paid. This is indeed related to the way it is perceived. Referring to the 1969 edition of the Random House Dictionary of the English Language, prostitution is defined as an "act or practice of engaging in sexual intercourse for money." ${ }^{33}$ Another definition rejects the point of selling ones body to distinguish prostitute and common women. Ellis, for instance, argues that it is also done every day by women who become wives in order to gain home and livelihood. Being not able to avoid a simplification, Edlund and Korn argue that a prostitute sells non-reproductive sex, "commercial sex," whereas a wife sells reproductive sex. ${ }^{44}$

Likewise, in the Pansus discussions, the most controversial debate

${ }^{41}$ The Final Faction Overview of the Fraksi Partai Golkar, the Fraksi Kesatuan Baru, and the Fraksi Partai Keadilan Sejahtera.

${ }^{42}$ Yon Machmudi, Islamising Indonesia: The Rise of Jemaab Tarbiyah and The Prosperous Justice Party (Canberra: ANU E Press, 2008), p. 195.

${ }^{43}$ Lena Edlund and Evelyn Korn, "A Theory of Prostitution," Journal of Political Economy, 110, 1, 2002.

${ }^{44}$ Ibid. 
was about what was prostitution and whose definition should be taken. Some make a categorisation dependent upon the presence of money. Nevertheless, this Perda does not make such a division. It declares that indecent (immoral) actions with or without financial compensation are regarded as prostitution. Despite being known as an old profession, it seems that the Perda ignores compound definitions of prostitution. The Perda defines prostitution as any action, done by a person or an institution, enticing, facilitating, organising, and committing indecent (vice) acts. Unlike before, by this definition, the grey area of the distinction between 'approval', 'acknowledgment', and 'prohibition' of prostitution has been clear to the government, the sex workers, the brothels, and the public.

It goes without saying that everyone can propose an argument of what factors throwing someone into prostitution. Koentjoro believes high material demands, cultural support, and poverty are the key factors. Meanwhile, in developed counties which have run social security policies, prostitution can still be found. Sex workers and prostitution develop in many ways and integrate themselves as part of social culture. In this regard, scholars are inclined to argue that prostitution practices have to be controlled due to four reasons: teasing a man who is not interested in prostitution, expanding its area to other parts, the spread of sexual diseases, and the increasing number of sex workers if brothels are permanently closed. ${ }^{45}$

In the debates on the Perda, some people also argue that prohibition was not a realistic option. ${ }^{46}$ Though insisting it was in favour of the position from early on, the PDI-P was somehow not convinced with the choice of prohibiting. That is why they held polling via mobile Short Message Service (SMS). The polling was conducted over two days, 10-11 April 2011 on Persatuan radio station. The public was offered two options, regulating or prohibiting. The options seem to neglect the fact that some groups are reluctant to have such a regulation. There was no clear definition on the distinction between regulation and prohibition. This polling can necessarily be seen as the PDI-P being very aware with

${ }^{45}$ Koentjoro, "Pelacuran sebuah Problema Sosial Multi-Perspektif," Jurnal Psikologia, vol. 4, no. 2, June 2009.

${ }^{46}$ Interview with Slamet Abdullah, a legislative member from PAN, on 10 August 2011. 
the mechanism of democracy and public participation in the legislative process. The polling reports 224 messages were received by the Persatuan radio. 45 people $(20.1 \%)$ were in favour with regulating, while the rest, $79.9 \%$, emphasised prohibition. This significant result pushed the PDI-P to legalise the draft. Prohibiting is a reasonable decision to be drawn. ${ }^{47}$

The democratic state, based on the engagement of various principles such as free, fair, competitive elections, an independent judiciary, often ignores or fails to underscore the importance of democratic quality. ${ }^{48}$ Komnas Perempuan relates this situation to the practice of 'procedural democracy' and 'substantive democracy. ${ }^{49}$ The first indicates that the policy making process tends to exploit the absence of public participation and accountability and to disregard the hegemony of the local majority's interest. Meanwhile, the second emphasises the creation of political interest and the state's intervention in religious fields which have played a decisive role in policy making. This practice has signalled a significant decline of the quality of Indonesian democracy. ${ }^{50}$

The use of procedural democracy could be misleading. Baynes, for instance, relates procedural democracy with what is called by Charles Beitz "complex proceduralism." This concept states that "the terms of democratic participation are fair when they are reasonably acceptable from each citizen's point of view, or more precisely, when no citizen has good reason to refuse to accept them." He also refers to Habermas's conception of procedural democracy which is placed as a contrast to two major political paths, liberal and republican. The first typically understands politics as an effort to aggregate private interests as well as to protect private property from public infringement. The later emphasises more the notion of citizens' public virtue and active political participation. Here, politics is placed as an instrument to build consensus of the common

${ }^{47}$ Interview with Tustiyani, the head of DPRD Bantul, July 2011.

${ }^{48}$ Rachael Chadwick, "The Quality of Democracy in Indonesia and Russia: A Path-Shaping Analysis of Two Fourth Wave Democracies," thesis submitted to the Department of Asian Studies, the University of Sydney, 2006.

49 This term, according to Przeworski, refers to a democracy system that generates expanded policy platforms, but does not rigidly require the outcomes of the policy process. The minimalist or procedural conception of democracy is a democratic government in which citizens select their leaders through competitive elections.

${ }^{50}$ Komnas Perempuan, Atas Nama Otonomi Daerah, p. 59. 
good, though law is not solely viewed as a tool for protecting individual rights, but as a manifestation of political aspirations. ${ }^{51}$

The common understanding of the above concept is, nonetheless, based on the problem of the state's treatment of a majority and minority. Procedural democracy has to do with the fulfilment of some basic conditions, such as universal participation and the government's responsiveness to public (majority) demands. However, the big question is whether or not it protects the rights of minorities. On the contrary, substantive democracy, focusing on the substance of government policies rather than embodied in the policymaking procedure, is developed. ${ }^{52}$

In addition to democracy and public participation, social illness and health was brought into play. The Golongan Karya (Functional Group, Golkar) party, referring to the result of the survey by the Health Office (Dinas Kesehatan) of Bantul, expressed its strong support to this bylaw. Survey of 285 samples in 2004 found 7 HIV (Human Immunodeficiency Virus) sufferers, while there were 6 sufferers out of 422 samples in the 2005 survey. Survey of 378 samples held in 2006 found 12 HIV sufferers, whilst the 2007 survey with a wider sampling found that among 403, 4 were suffered. ${ }^{53}$ The decrease of sufferers in 2007 was claimed to be the positive effect of this enforced regulation.

Gender activists were subject to this justification since none of 12 articles within the Perda speak about the prevention of the spread of HIV virus. Some of them refer to the Western case that in the early 1990s policy makers in Europe and America carefully concluded that prostitution played no major part in reducing the spread of HIV. Instead, the need of practice 'safe sex' is always campaigned. The distribution of condoms and lubricants by the newly established agencies is believed to be strategic part of harm minimisation. People are encouraged to regularly have medical check-ups with the guarantee of a friendly confidential service in areas where prostitution is extensive. Health workers are

${ }^{51}$ Kenneth Baynes, "Deliberative Democracy and the Limits of Liberalism" in René von Schomberg and Kenneth Baynes (eds), Discourse and Democracy: Essays on Habermas's Between Facts and Norms (New York: State University of New York Press, 2002), p. 17.

${ }^{52}$ Kenneth Janda, et. al., The Challenge of Democracy: American Government in a Global World (Brief Edition) (Boston: Wadsworth Cengage Learning, 2009), pp. 22-23.

${ }^{53}$ www.aids-ina.org 
appointed to see sex workers and enrol their participation in regular check-ups and HIV prevention activities. ${ }^{54}$

\section{F. Conclusion}

The issuance of the Bantul bylaw on prostitution is an example of one of many regulations on morality and social order. Some key concepts appearing in the regulation include violating religious teachings, human dignity, Pancasila and health. The fact that Bantul is inhabited by rural Muslims has served as a basis for political parties, Islamic or nationalist. In addition, the rise of PKS and PD and the decline of PDI-P is another socio-political factor behind the appearance of the regulation. The battleground provides a situation where the political parties find themselves struggling and speaking for Islam or Muslim interests.

Despite no single definition of prostitution, contestation over the meaning of prostitution as stated in the Perda occurred. The border and limitation of prostitution is deemed unclear. Its definition is even extended not only to those directly linked to sexual activities, sex workers and pimps, but everyone who looks or behaves like a prostitute.

${ }^{54}$ Roger Matthews, Prostitution, Politics and Policy (New York: Routledge, 2008), p. 3. 


\section{BIBLIOGRAPHY}

Bantul Statistics Bureau, Bantul in Figures, Bantul: BPS, 2008.

Baynes, Kenneth, "Deliberative Democracy and the Limits of Liberalism" in René von Schomberg and Kenneth Baynes (eds), Discourse and Democracy: Essays on Habermas's Between Facts and Norms, New York: State University of New York Press, 2002.

Bush, Robin, "Regional Sharia Regulations in Indonesia: Anomaly or Sympton?" in Greg Fealy and Sally White (eds), Expressing Islam: Religious Life and Politics in Indonesia, Singapore: Institute of Southeast Asian Studies, 2008.

Chadwick, Rachael, "The Quality of Democracy in Indonesia and Russia: A Path-Shaping Analysis of Two Fourth Wave Democracies," Thesis submitted to the Department of Asian Studies, the University of Sydney, 2006.

Edlund, Lena and Evelyn Korn, “A Theory of Prostitution,” Journal of Political Economy, 110, 1, 2002, pp. 181-214.

Janda, Kenneth, et. al., The Challenge of Democracy: American Government in a Global World (Brief Edition), Boston: Wadsworth Cengage Learning, 2009.

Jones, Gavin W., Endang Sulistyaningsih, and Terence H. Hull, "Prostitution in Indonesia," Working Paper in demography at the Australian National University, 1995.

Kantola, Johanna and Judith Squires, "Discourses Surrounding Prostitution Policies in the UK, "European Journal of Women's Studies, 11, 1, 2004, pp. 77-101.

Koentjoro, "Pelacuran sebuah Problema Sosial Multi-Perspektif," Jurnal Psikologia, vol. 4, no. 2, June 2009, pp. 70-74.

Komnas Perempuan, Atas Nama Otonomi Daerah: Pelembagaan Diskriminasi dalam Tatanan Negara-Bangsa Indonesia, Jakarta: Komnas Perempuan, 2010.

----, Berita Komnas Perempuan, Edition 5, September 2010.

Liddle, R. William, "New Patterns of Islamic Politics in Democratic Indonesia," Asia Program Special Report, Woodrow Wilson Center 
International Center for Scholars, no. 110, April 2003.

Machmudi, Yon, Islamising Indonesia: The Rise of Jemaah Tarbiyah and The Prosperous Justice Party, Canberra: ANU E Press, 2008.

Maharsi, "Varian Keagamaan Masyarakat Pesisir Pantai Selatan (Studi Kasus Desa Parangtritis, Kretek, Bantul, DIY)," Jurnal Penelitian Agama, 13, 3, September-December 2004.

Matthews, Roger, Prostitution, Politics and Policy, New York: Routledge, 2008.

Ufen, Andreas, "From Aliran to Dealignment: Political Parties in postSuharto Indonesia," South East Asia Research, 16, 1, pp. 5-41.

----, "The Evolution of Cleavages in the Indonesian Party System," Working Paper at the German Institute of Global and Area Studies, April 2008.

Weitzer, Ronald, "Legalizing Prostitution: Morality Politics in Western Australia," The British Journal of Criminology, 49: 1 (2009) pp. 88-105.

\section{Interviews}

Interview with Ahmad, the imam of the Darus Salam mosque, August 2011.

Interview with Anik, the caretaker of sex workers, July 2011.

Interview with Budi, the owner of Hesty Karaoke in Parangkusumo, July 2011.

Interview with Daru Waskita, journalist, in Bantul, July 2011.

Interview with RP Suraksotarwono, the spiritual guardian, August 2011. Interview with Slamet Abdullah, a legislative member from PAN, August 2011.

Interview with Tustiyani, the head of DPRD Bantul, July 2011.

Interview with Yani, sex worker, in Parangkusumo, July 2011. 